\title{
Epidemiology of mouldy core and core rot of apple in Himachal Pradesh, India
}

\author{
HANS RAJ $^{1 *}$, J. N. SHARMA ${ }^{2}$ and DHARMESH GUPTA ${ }^{2}$ \\ ${ }^{1}$ Advanced Research Centre for Bamboo and Rattan, Aizawl 796 001, Mizoram, India \\ ${ }^{2}$ Department of Mycology and Plant Pathology, Dr. Y.S. Parmar University of Horticulture and Forestry, Nauni, Solan 173230 , \\ Himachal Pradesh, India
}

Received: 27 December 2016/ Accepted: 14 February 2017/ Published online: 23 March 2017

(C) Indian Phytopathological Society 2017

\begin{abstract}
Mouldy core and core rot of apple caused by Alternaria alternata has emerged an economically important disease in Himachal Pradesh, India causing direct losses to the growers. The fungus remains dormant inside the calyx of the fruit and later becomes active when the starch content of the fruits get converted into sugar and hence causes the post harvest disease, where the rotting of the fruits starts from the core region. In vitro studies on the effect of temperature and relative humidity on the growth of the conidia of Alternaria alternata causing mouldy core and core rot of apple revealed that, the temperature of $30^{\circ} \mathrm{C}$ and 100 per cent relative humidity were optimal for conidial germination. Among different weather parameters, cumulative rainfall was directly correlated with disease development. Regression analysis further showed that 91.00 per cent variation in pre-harvest fruit drop was due to mouldy core and core rot. Medium sized Starking Delicious apple fruits with open sinus/calyx tube and length: width ratio falling in 0.96 to $1.05 \mathrm{~mm}$ showed maximum incidence of mouldy core and core rot in the field.
\end{abstract}

Keywords: Alternaria alternata, apple, epidemiology, mouldy core and core rot

Apple (Malus $x$ domestica Borkh.), a member of family Rosaceae is the most important fruit crop grown extensively in temperate regions all over the world. In India, it is commercially grown in the Himalayan region including the states of Jammu and Kashmir, Himachal Pradesh and Uttarakhand and to a limited extent in North Eastern states viz. Arunachal Pradesh, Sikkim, Nagaland and Meghalaya with total annual production of 21,34, 000 metric tonnes (Anonymous, 2015a). Its cultivation has revolutionized the socio-economic condition of hilly farmers in the state and has become the number one commercial fruit crop, which is being grown over an area of $1,10,000$ ha. with an annual production of $6,25,000$ metric tonnes (Anonymous, 2015b). With the intensive cultivation this crop in the state some new disease problems have cropped up over a fairly large area. More recently, a new problem of pre-harvest fruit drop associated with core rot has been encountered in major fruit growing areas of Shimla and Kullu districts of Himachal Pradesh, India (Gupta and Sharma, 2008). Preliminary studies have indicated the association of several fungi involved in mouldy core and core rot of dropped as well as fully mature apple fruit on the trees, but Alternaria alternata was reported to be the predominant fungal pathogen responsible for the disease in different regions of the world (Gao et al., 2013; Ntasiou et al., 2015; Reuveni, 2006; Sharma et al., 2013). The term mouldy core has been used to describe the situation where the fungal mycelium is evident within the core

*Corresponding author: hansraj@icfre.org without causing penetration in to the flesh or mesoderm of apple. If invasive penetration into the apple flesh is present, the resultant rot is commonly described as a core rot (Ntasiou et al., 2015). Once inside the fruit, the fungus is protected against contact fungicide and conditions for its growth are excellent. Fruit infection occurs either during flowering or as a consequence of post-harvest infections primarily through dip treatment of the fruits when the fruits are dipped in contaminated water in the packinghouse rather than from field infections (Archer, 2002). However, there is still a wide gap in information regarding epidemiology of the disease. Hence the present investigations were undertaken to find out optimum conditions for the growth and development of the pathogen under field conditions.

\section{MATERIALS AND METHODS}

\section{Effect of temperature and relative humidity on conidial germination}

To find out the optimum temperature required for germination of conidia of $A$. alternata harvested from fresh culture, one $\mathrm{ml}$ of the standardized conidial suspension containing 50 conidia per microscopic field was prepared, of which one drop was put on the cavity slides. The cavity slides were then placed on glass rods in the $9 \mathrm{~cm}$ diameter Petri plates lined with the wet sterilized blotting papers to maintain high relative humidity and incubated at different temperatures viz., 
$15,20,25,30$ and $35+1^{\circ} \mathrm{C}$ in BOD incubators. Each treatment was replicated four times. Observations on conidial germination and germ tube length were recorded after 18 and 24 hours of incubation.

To maintain the relative humidity levels of $100,92.9$, $82.9,75.6,66.8,46.8$ and 36.8 per cent, solutions of 0 , $15,25,30,35,45$ and 50 per cent sulphuric acid, respectively were prepared and poured in different Petri plates. One drop of the conidial suspension containing approximately $5 \times 10^{4}$ conidia/ml was placed on cavity slides. The slides were kept in the Petri plates at different humidity levels and incubated at $25 \pm 1^{\circ} \mathrm{C}$. Observations on per cent conidial germination and germ tube length were recorded after 24 hours of incubation.

\section{Effect of weather parameters on disease development}

To find the effect of different weather parameters on the disease incidence the data on weather parameters were taken from meteorological observatory at Temperate Horticulture Research Station, Kotkhai of Dr. Y.S. Parmar University of Horticulture and Forestry, Nauni, Solan, Himachal Pradesh, India starting from $1^{\text {st }}$ January to $31^{\text {st }}$ August, 2008 and 2009. The data were subjected to analysis and simple, partial and multiple correlation coefficients were worked out between disease incidence and air temperature, relative humidity and rainfall.

\section{Effect of host characteristics on disease development}

To see the effect of different host characteristics such as openness of sinus/calyx tube, shape of fruits ( $\mathrm{L}: \mathrm{W}$ ratio), size/weight of fruit of Starking Delicious cultivar on the incidence of mouldy core and core rot, intact fruit sample (5 each) of the same cultivar was selected randomly from
50 different trees in a orchard and brought to the laboratory for the observations of different characteristics and presence of the diseases. Open sinus/calyx tube was observed by cutting the fruits into two halves, while length: width ratio and size of the fruits were measured with the help of the vernier calliper.

\section{RESULTS AND DISCUSSION}

\section{Effect of temperature and relative humidity on spore germination and germ tube length}

Maximum conidial germination (73.75\%) of Alternaria alternata was recorded at $30^{\circ} \mathrm{C}$, which was statistically superior to other treatments followed by $35,25,20$ and $15^{\circ} \mathrm{C}$. The temperature regimes ranging from 30 to $35^{\circ} \mathrm{C}$ were found optimum for conidial germination of the pathogen. The results of the data with regard to the conidial germ tube length of the pathogen after 24 hours revealed almost similar trend. Maximum germ tube length $(116.8 \mu \mathrm{m})$ was recorded at $30^{\circ} \mathrm{C}$ followed by 115.61 $\mu \mathrm{m}$ at $25^{\circ} \mathrm{C}$, though both were statistically at par. However, minimum germ tube length $(64.16 \mu \mathrm{m})$ was recorded at $15^{\circ} \mathrm{C}$. It is evident from the data that the conidia of Alternaria alternata could germinate over a wide range of relative humidity $(46.8-100 \%)$. The maximum conidial germination $(95.40 \%)$ was recorded at 100 per cent relative humidity which was statistically superior to other treatments followed by 92.6, 82.0, 75.6, 66.8 and 46.8 per cent in descending order. No conidial germination was observed at 36.8 per cent relative humidity. Maximum germ tube length $(226.70 \mu \mathrm{m})$ was recorded against at 100 per cent followed by 92 per cent $(189.06 \mu \mathrm{m})$, but different significantly from each other. However, minimum germ tube length $(9.23 \mu \mathrm{m})$ was recorded at 46.8 per cent relative humidity.

Table 1. Effect of temperature and relative humidity on the conidial germination of Alternaria alternata causing mouldy core and core rot of apple

\begin{tabular}{|c|c|c|c|c|}
\hline \multirow[t]{2}{*}{ Temperature $\left({ }^{\circ} \mathrm{C}\right)$} & \multicolumn{2}{|c|}{ Conidial germination (\%) } & \multicolumn{2}{|c|}{ Germ tube length $(\mu \mathrm{m})$} \\
\hline & 18 hours & 24 hours & 18 hours & 24 hours \\
\hline 15 & $12.29(20.51)$ & $20.88(27.14)$ & 39.28 & 64.16 \\
\hline 20 & $24.62(29.74)$ & $34.99(36.26)$ & 60.70 & 87.27 \\
\hline 25 & $54.16(47.39)$ & $67.50(55.25)$ & 90.17 & 115.61 \\
\hline 30 & $54.58(47.63)$ & $73.75(59.20)$ & 88.42 & 116.80 \\
\hline 35 & $53.95(47.27)$ & $72.91(58.65)$ & 80.62 & 97.14 \\
\hline $\mathrm{CD}_{0.05}$ & $2.02(8.53)$ & $1.27(6.30)$ & 0.58 & 1.08 \\
\hline
\end{tabular}

\begin{tabular}{lcc} 
Relative humidity $(\%)$ & Conidial germination $(\%)$ & Germ tube length $(\mu \mathrm{m})$ \\
\hline 100.0 & $95.40(77.63)$ & 226.70 \\
92.0 & $92.25(72.82)$ & 189.06 \\
82.0 & $71.23(57.56)$ & 86.60 \\
75.6 & $65.00(53.73)$ & 26.80 \\
66.8 & $54.72(47.71)$ & 19.26 \\
46.8 & $17.83(24.98)$ & 9.23 \\
36.8 & $0.00(0.00)$ & 0.00 \\
$C D_{0.05}$ & $1.80(1.89)$ & 1.58
\end{tabular}

Figures in parentheses are arc sine transformed values 


\section{Effect of weather parameters on disease development}

To find out the relationship of disease incidence with the environmental factors viz., temperature, relative humidity and rainfall; observations on disease incidence and fruit drop were recorded at monthly intervals in the farmer's field at Kotkhai and were correlated with the weather data. It is evident from the figure 1 and 2 that, fruit drop in apple started in the field in month of May and progressed continuously up to harvesting of the fruits. Observations recorded on the dropped fruits during May showed no appearance of mouldy core and core rot disease in the field. However, when the dropped fruits were collected June onwards at monthly intervals, there was a progressive increase in the disease incidence which was maximum in the month of August. It was also observed that there was a definite relationship between disease incidence and temperature, relative humidity and rainfall.

\section{Simple and partial correlation}

Simple and partial correlation coefficients were calculated from the data to find out relationship between disease incidence and different factors like temperature, relative humidity and rainfall during 2008 and 2009. It is evident from the data that all the parameters were positively correlated with per cent fruit drop and the incidence of mouldy core and core rot of apple in both the years. However, rainfall showed a highly significant correlation with the disease, during 2008 and 2009 cropping seasons. Partial correlation coefficients were also calculated to find out the relationship between each of these three factors with disease incidence and fruit drop, keeping the other two factors constant. It is apparent from the data that per cent incidence of fruit drop, mouldy core and core rot exhibited a positive and significant correlation with rainfall when temperature and relative humidity were kept constant during both the years. Although other factors like temperature and relative humidity also showed a positive correlation with the disease in both the years.

\section{Multiple regression equation}

In order to find out the total effect of temperature, relative humidity and rainfall on disease incidence and preharvest fruit drop of apple during the year 2008 and 2009 , multiple regression equation was fitted between these factors and the results are presented below. It was evident from multiple regression equations that $1^{\circ} \mathrm{C}$ rise in temperature and $1 \mathrm{~mm}$ increase in rainfall caused 0.42 and 0.05 per cent increase in pre-harvest fruit drop respectively, during the year 2008 while with the increase in 1 per cent relative humidity there was 0.02 per cent decrease in fruit drop. Almost similar trend was obtained during the year 2009. The equations further signify that a rise in temperature by 1 degree resulted in 0.39 per cent decrease in disease incidence of mouldy core and an increase in relative humidity by 1 per cent and rainfall by $1 \mathrm{~mm}$ resulted in 0.08 and 0.84 per cent increase in disease incidence of mouldy core during the year 2008 .
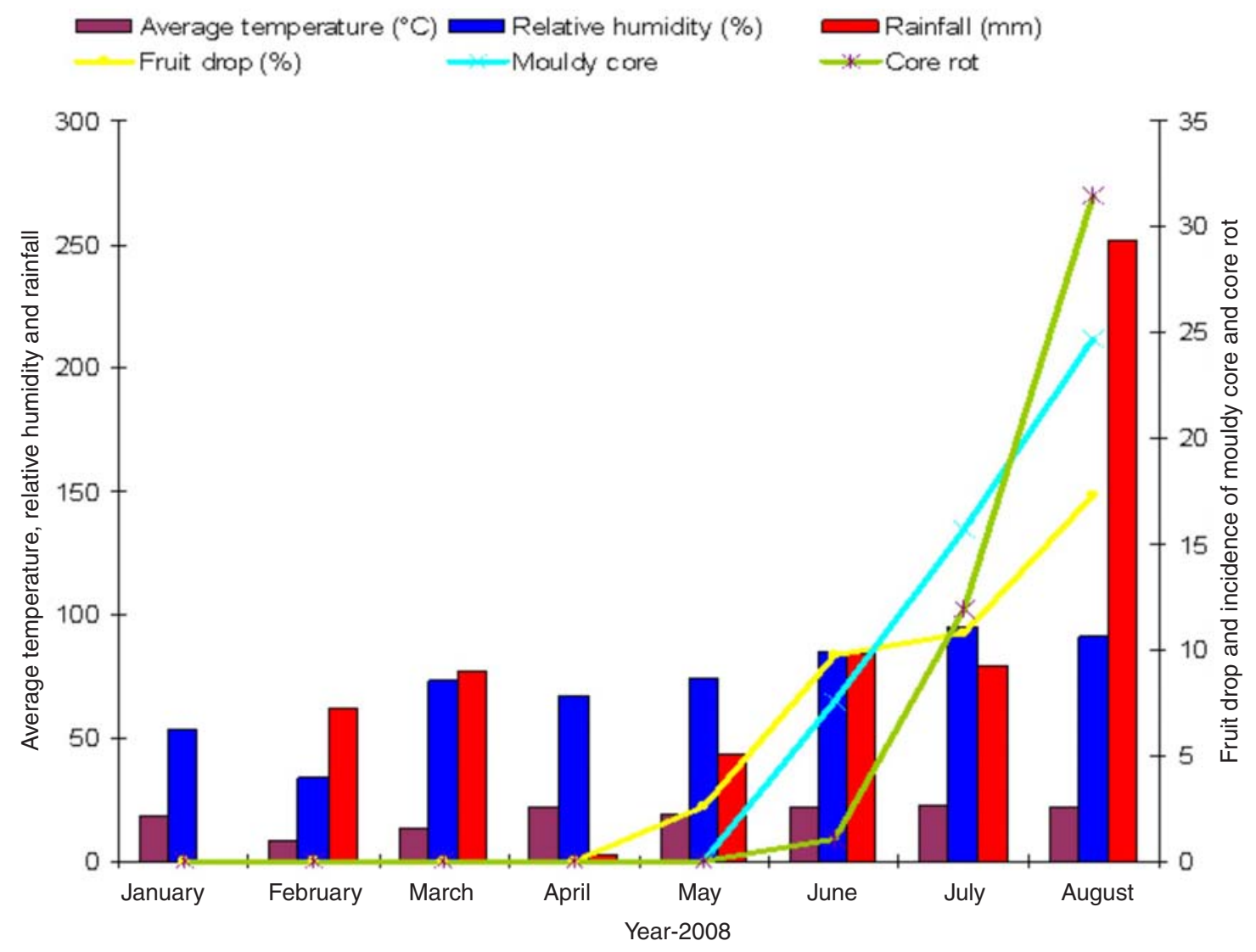

Fig. 1. Effect of weather parameters on the incidence of preharvest fruit drop, mouldy core and core rot of apple during 2008 season 


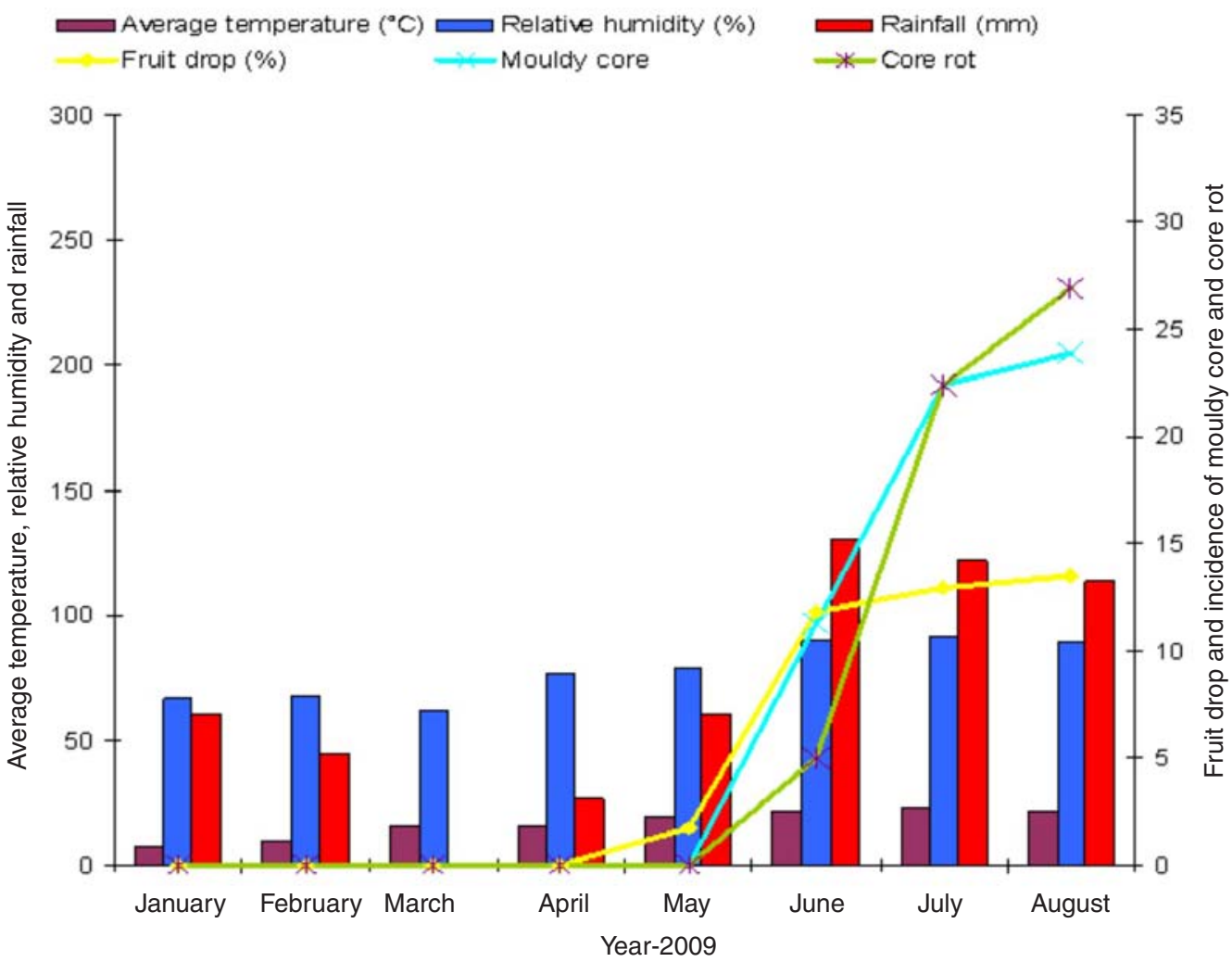

Fig. 2. Effect of weather parameters on the incidence of preharvest fruit drop, mouldy core and core rot of apple during 2009 season

Table 2. Simple and partial correlation coefficients between weather parameters and incidence of pre-harvest fruit drop, mouldy core and core rot during 2008 and 2009

\begin{tabular}{|c|c|c|c|c|c|c|}
\hline \multirow[t]{2}{*}{ Parameter } & \multicolumn{3}{|c|}{ Simple correlation coefficients } & \multicolumn{3}{|c|}{ Partial correlation coefficients } \\
\hline & Fruit drop & Mouldy core & Core rot & Fruit drop & Mouldy core & Core rot \\
\hline Average Temperature & 0.6075 & 0.6423 & 0.5348 & $0.6197^{*}$ & 0.4917 & 0.3735 \\
\hline Relative humidity & $0.7653^{*}$ & 0.7122 & 0.6525 & 0.2540 & 0.5448 & 0.4288 \\
\hline Rainfall & $0.7831^{*}$ & $0.8434^{\star *}$ & $0.8643^{\star \star}$ & $0.6806^{*}$ & $0.8129^{* *}$ & $0.7914^{*}$ \\
\hline
\end{tabular}

* significant, ${ }^{* *}$ highly significant

A similar trend was again observed during the year 2009. Similarly, in case of core rot temperature and rainfall were directly correlated with disease incidence during the year 2008 and 2009 and effect of relative humidity was variable. The coefficient of multiple determination was calculated to be 0.8140 for fruit drop which signifies that 81.40 per cent variation in fruit drop was influenced by the prevailing weather parameters. Similarly, coefficients of multiple determination for mouldy core and core rot were calculated to be 70.00 and 71.00 respectively, thereby signifying that 70 and 71 per cent variation in mouldy core and core rot, respectively depended on weather parameters in the study.

\section{Multiple regression equation for pre-harvest fruit drop vis-a-vis mouldy core and core rot during 2008 and 2009}

In order to find out the effect of mouldy core and core rot disease in the causation of pre-harvest fruit drop of apple during the year 2008 and 2009, multiple regression equation was fitted between these factors. It is evident from the multiple regression equations that with 1 per cent rise in incidence of mouldy core and core rot, there was 1.10 and 0.50 per cent increase in pre harvest fruit drop, respectively during the year 2008, thus indicating that the disease was responsible for preharvest fruit drop in apple. Similarly, it was also directly correlated with preharvest fruit drop during the year 2009.

The coefficients of multiple determinations were calculated to be 0.9100 and 0.90 .60 , respectively during the year 2008 and 2009 seasons which showed that 91.00 and 90.60 per cent variation in fruit drop was due to mouldy core and core rot.

\section{Effect of host characteristics on the incidence of mouldy core and core rot}

Openness of sinus/calyx tube: On examination of 260 intact fruits taken randomly from 52 different Starking 
Table 3. Multiple regression equation indicating relationship among weather parameters and disease incidence during 2008 and 2009

\begin{tabular}{|c|c|c|c|c|c|c|}
\hline \multirow{2}{*}{$\frac{\text { Year }}{2008}$} & \multirow[b]{2}{*}{$Y_{1}=$} & \multicolumn{3}{|c|}{ Regression equation } & & \multirow{2}{*}{$\begin{array}{l}R^{2}(\%) \\
81.40\end{array}$} \\
\hline & & $\begin{array}{c}7.64 \\
(7.043)\end{array}$ & $\begin{array}{c}+0.423 \mathrm{~T} \\
(0.188)\end{array}$ & $\begin{array}{c}-0.026 \mathrm{RH} \\
(0.108)\end{array}$ & $\begin{array}{c}+0.053 R F \\
(0.017)\end{array}$ & \\
\hline & $Y_{2^{-}}=$ & $\begin{array}{c}-13.386 \\
(13.59)\end{array}$ & $\begin{array}{r}-0.392 \mathrm{~T} \\
(0.367)\end{array}$ & $\begin{array}{c}+0.080 \mathrm{RH} \\
(0.209)\end{array}$ & $\begin{array}{c}+.084 \mathrm{RF} \\
(0.034)\end{array}$ & 70.00 \\
\hline & $Y_{3}=$ & $\begin{array}{l}-0.409 \\
(15.97)\end{array}$ & $\begin{array}{c}+0.306 \mathrm{~T} \\
(0.427)\end{array}$ & $\begin{array}{c}-0.125 \mathrm{RH} \\
(0.246)\end{array}$ & $\begin{array}{c}+0.136 R F \\
(0.04)\end{array}$ & 71.00 \\
\hline \multirow[t]{3}{*}{2009} & $Y_{1}=$ & $\begin{array}{c}-0.712 \\
(18.94)\end{array}$ & $\begin{array}{c}+0.727 \mathrm{~T} \\
(0.404)\end{array}$ & $\begin{array}{c}-0.132 \mathrm{RH} \\
(0.355)\end{array}$ & $\begin{array}{c}+0.069 R F \\
(0.06)\end{array}$ & 74.10 \\
\hline & $Y_{2^{-}}=$ & $\begin{array}{l}-8.497 \\
(43.99)\end{array}$ & $\begin{array}{c}-0.729 \mathrm{~T} \\
(0.938)\end{array}$ & $\begin{array}{c}-0.085 \mathrm{RH} \\
(0.824)\end{array}$ & $\begin{array}{c}+0.145 R F \\
(0.140)\end{array}$ & 57.50 \\
\hline & $Y_{3}=$ & $\begin{array}{l}-15.03 \\
(61.42)\end{array}$ & $\begin{array}{c}+0.622 \mathrm{~T} \\
(1.31)\end{array}$ & $\begin{array}{c}+0.049 \mathrm{RH} \\
(1.15)\end{array}$ & $\begin{array}{c}+0.109 R F \\
(0.196)\end{array}$ & 26.30 \\
\hline
\end{tabular}

Where

$Y_{1}=$ Fruit drop (\%); $Y_{2}=$ Disease incidence (\%) of Mouldy core; $Y_{3}=$ Disease incidence (\%) of Core rot

$\mathrm{T}=$ Average temperature; $\mathrm{RH}=$ Average relative humidity; $\mathrm{RF}=$ Cumulative rainfall

Delicious apple trees ( 5 each) 57 fruits were found to be infected with the mouldy core and out of these 43 (75.43\%) showed open calyx tube. Similarly, 9 (75.00\%) out of 12 infected fruits showed the open calyx tube.

Length : width ratio: Twenty apple fruits of each class were collected randomly from different trees and the disease incidence of mouldy core and core rot of the fruits falling in the classes were calculated (Table 4). The data revealed that the maximum incidence of the disease was observed in the fruits falling in the $L: W$ ratio class 0.96-1.05 mm followed by 0.86-0.95 mm class. However, no disease was observed in the fruits falling below 0.75 $\mathrm{mm} \mathrm{L}: \mathrm{W}$ ratio class. The study reveals that the disease was more prevalent in the medium sized fruits.

Fruit size: The disease incidence in twenty Starking Delicious apple cultivar fallen fruits, collected randomly from different trees were measured in each size categories was calculated. The data presented in the above table revealed that the maximum incidence of mouldy core $(20.0 \%)$ and core rot $(12.5 \%)$ was recorded in the medium and extra large size fruits, respectively. However, on an average medium size fruits showed the maximum (28.1\%) cumulative disease incidence among the different size classes. Whereas, minimum disease incidence $(8.3 \%)$ was recorded in pittoo size fruits

\section{DISCUSSION}

In this disease of apple not much work has been done in India on the epidemiological aspects. Varying temperature ranges has a deciding influence on the inoculums' build up and spread. Effect of temperature on conidial germination of $A$. alternata the predominant fungal pathogen associated with mouldy core and core rot of apple, was studied under laboratory conditions. A temperature of $25-30^{\circ} \mathrm{C}$ was optimum for the germination of conidia and germ tube length respectively. These results are in conformity with the findings of earlier workers who have reported conidial germination of Alternaria alternata ranging from $25-30^{\circ} \mathrm{C}$ (Sharma et al., 2005; Sevamani et al., 2014).

The results on the effect of relative humidity on conidial germination are in conformation with the findings of Sharma et al. (2005) who reported the maximum conidial germination and germ tube length at 100 per cent relative humidity.

The present studies indicated a direct correlation of the disease with rainfall and regression analysis revealed that around 81, 70 and 71 per cent disease incidence depended on the environmental factors in the development of fruit drop, mouldy core and core rot,

Table 4. Effect of length: width ratio and size of fruits of Starking Delicious cultivar on the incidence of mouldy core and core rot of apple

\begin{tabular}{|c|c|c|c|c|c|c|c|}
\hline \multirow{2}{*}{$\begin{array}{l}\mathrm{L}: \mathrm{W} \text { ratio } \\
(\mathrm{mm})\end{array}$} & \multicolumn{3}{|c|}{ Per cent disease } & \multirow[t]{2}{*}{ Size category $(\mathrm{mm})$} & \multicolumn{3}{|c|}{ Per cent disease } \\
\hline & MC & $\mathrm{CR}$ & $C D$ & & $\mathrm{MC}$ & CR & $C D$ \\
\hline$<0.75$ & 0.00 & 0.00 & 0.00 & Pittoo $(<55)$ & 8.30 & 0.00 & 8.30 \\
\hline $0.76-0.85$ & 13.30 & 0.00 & 13.30 & Extra small $(56-60)$ & 10.70 & 3.60 & 14.30 \\
\hline $0.86-0.95$ & 27.42 & 6.45 & 33.87 & Small (61-65) & 18.10 & 6.00 & 24.10 \\
\hline $0.96-1.05$ & 29.33 & 12.00 & 41.33 & Medium (66-70) & 20.00 & 8.10 & 8.10 \\
\hline $1.06-1.15$ & 13.80 & 0.00 & 13.80 & Large $(71-75)$ & 17.70 & 5.70 & 23.40 \\
\hline \multirow[t]{2}{*}{$>1.15$} & 7.15 & 0.00 & 7.15 & Extra Large $(76-80)$ & 6.30 & 12.50 & 18.80 \\
\hline & & & & Super Large $(>80)$ & 7.20 & 7.10 & 14.30 \\
\hline
\end{tabular}

Where $\mathrm{MC}=$ mouldy core, $\mathrm{CR}=$ core rot and $\mathrm{CD}=$ Cumulative disease 
respectively during 2008 and 74,57 and 26 per cent in 2009 season. Thakur and Sharma (2010) reported that $70.38,53.47$ and 35.03 variations have been contributed by temperature, relative humidity and rainfall, respectively in the development of apple blotch complex caused by Marssonia and Alternaria sp. whereas, the rest of variations were due to unexplained factors.

Multiple regression equation showed that more than 90 per cent variation in fruit drop during 2008 and 2009 was due to mouldy core and core rot fruit infection, thus indicating the involvement of this disease in the preharvest fruit drop. The result of the study was confirmatory with Gupta and Sharma (2008) reported the occurrence of water core and core rot infection in dropped fruits. Reuveni et al. (2003) reported that external symptom was rare but, mouldy core infected fruits dropped prematurely.

Medium sized fruits with open sinus/calyx tube and length: width ratio falling between 0.96 to $1.05 \mathrm{~mm}$ showed the maximum incidence of mouldy core and core rot in the field. These findings are in accordance with those of Shtienberg (2012) who reported that core rot was more abundant on large fruits as compared to small size fruits in Israel. Ellis and Barrat (1983) reported that the fungus Alternaria sp. colonizes the flower parts during the shortly after bloom and later moved, presumably through the open calyx tube in to the receptacle or core regions and cause the mouldy core in Delicious apples. Spotts et al. (1988) reported that maximum incidence of wet core rot was present in fruits falling above $0.91 \mathrm{~mm}$ length: width ratio class. Combrink et al. (1985) reported that open calyx tube typical of Starking Delicious apples allowed free access of pathogen into the core cavity of the fruits causing core rot.

\section{ACKNOWLEDGEMENTS}

The authors are grateful to Dr. S.K. Sharma, Professor and Head, Department of Mycology and Plant Pathology, Dr. Y.S. Parmar University of Horticulture and Forestry, Nauni-Solan, Himachal Pradesh, India for providing research facilities and also to Jitender Singh and B.R. Tajta, Orchardist, Kotkhai, district Shimla, Himachal Pradesh for providing apple orchard to conduct the field trial and collection of mouldy core and core rot samples.

\section{REFERENCES}

Anonymous (2015a). National Horticulture Board, Ministry of Agriculture, Govt. of India.
Anonymous (2015b). National Horticulture Board, Ministry of Agriculture, Govt. of India.

Archer C (2002). The use of honeybees as a transfer vector for core rot in apples. Publication No. 02/046 RIRDC Project No TAR-1A. Rural Industries Research and Development Corporation. Barton, Kingston, Australia.

Combrink JC, Kotze JM and Visagie TS (1985). Colonisation of apple by fungi causing core rot. Hortic. Sci. 2: 9-13.

Ellis MA and Barrat JG (1983). Colonization of apple fruits by Altemaria sp. and effect of fungicide sprays on mouldy core. Plant Dis. 67: 150-152.

Gao LL, Zhang Q, Sun XY, Jiang L, Zhang R, Sun GY, Zha YL and Biggs AR (2013). Etiology of moldy core, core browning, and core rot of Fuji apple in China. Plant Dis. 97: $510-516$

Gupta Dharmesh and Sharma JN (2008). Natural occurrence of water core and core rot of apple in Himachal Pradesh (abstract). Indian Phytopath. 61: 386.

Ntasiou P, Myresiotis C, Konstantinou S, Papadopoulou Mourkidou E and Karaoglanidis GS (2015). Identification, characterization and mycotoxigenic ability of Alternaria species causing core rot of apple fruit in Greece. Int. J. Food Microbiol. 197: 22-29.

Reuveni M and Sheglov D (2002). Effects of azoxystrobin, difenoconazole, polyoxin B (polar), and trifloxystrobin on germination and growth of Altemaria alternata and decay in Red Delicious apple fruit. Crop Prot. 21: 951 -955.

Reuveni M (2006). Inhibition of germination and growth of Alternaria alternata and mouldy-core development in Red Delicious apple fruit by Bromuconazole and Sygnum. Crop Prot. 25: 253-258.

Selvamani R Pandian RTP and Sharma Pratibha (2014). Role of weather on Alternaria leaf spot development in crucifers. Indian Phytopath. 67: 285-290.

Sharma JN, Gupta Dharmesh, Bhardwaj LN and Kumar Ravinder (2005). Occurrence of Alternaria leaf spot (Alternaria alternata) on apple and its management. In: Integrated Disease Management by Sharma JN and Sharma RC (Eds.). Scientific Publishers (India). Jodhpur. pp 25-31.

Sharma IM, Negi HS and Kholsa K (2013). Prevalence, diagnosis and management of core rot in apple fruits. $J$. Mycol. Plant Pathol. 43: 261-270.

Shtienberg D (2012). Effects of host physiology on the development of core rot, caused by alternaria alternata, in Red Delicious apples. Phytopathology 102: 769778.

Spotts RA, Holmes RJ and Washington WS (1988). Factors affecting wet core rot of apple. Australas. Plant Pathol. 17: 53-57.

Thakur VS and Sharma Nirupma (2010). Epidemic outbreak of apple blotch disease: epidemiology and management in Himachal Pradesh. Indian Phytopath. 63: 141-144. 